\title{
The Wastewater Disposal System Modernization during Processing of Amber Deposit as a Way to Reduce the Anthropogenic Load on the Baltic Sea Ecosystem
}

\author{
Alexey V. Strizhenok ${ }^{1 *}$, Denis S. Korelskiy ${ }^{1}$, Vladimir S. Kuznetsov ${ }^{1}$ \\ 1 Saint-Petersburg Mining University, Vasilyevsky Island, 21st line 2, 199106, Saint-Petersburg, Russia \\ * Corresponding author's e-mail: alexeystrizhenok@mail.ru
}

\begin{abstract}
The research is devoted to assessing the negative impact of the amber-succinite deposit in the Kaliningrad region as one of the sources of complex pollution of the Baltic Sea waters. The Baltic Sea is one of the most polluted water bodies in Europe today. There are many natural and anthropogenic factors that cause this ecological situation. Industry is one of the significant contributors to the pollution of the waters of the Baltic Sea. The industrial wastewater discharged into the Baltic Sea often does not comply with the state ecological standards. The wastewater disposal system modernization by creating a recycled water supply is one of the most effective ways to reduce the negative impact of industrial wastewater on the Baltic Sea ecosystem nowadays. This technological solution allows to significantly reduce or to completely prevent the discharge of wastewater into the Baltic Sea.
\end{abstract}

Keywords: wastewater discharge, pollution, environmental monitoring, Baltic Sea, ecosystem, tailing dump, amber-succinite, recycled water supply.

\section{INTRODUCTION}

The Baltic Sea is a unique ecological system, an integral part of the global ecosystem . It is in dire need of protection from the destructive anthropogenic impact caused by the production and consumption of nuclear energy and artificial radio nuclides, agriculture, transportation of petroleum and petroleum products, industrial and municipal wastewater, as well as solid waste [Kartamysheva and Ivanchenko 2017].

The Baltic Sea is one of the most polluted seas of Europe today. Most of its territory is currently classified as «affected by eutrophication» [Vesman 2012]. The natural balance of the Baltic Sea is seriously disturbed by excessive nutrient inputs (nitrogen and phosphorus) as a result of the human activity. The sources of these substances are agricultural land, air emissions, power plants, industrial facilities and fish farms, as well as wastewater treatment plants. Annually, the Baltic Sea receives nutrients, averaging 640 thousand tons of nitrogen and 30 thousand tons of phosphorus, as well as a significant amount of heavy metals and chemicals that are products of pesticides decomposition [Wastewater treatment 2009].

In addition to the intensive anthropogenic impact, the degree of pollution of the Baltic Sea is greatly increased due to natural factors. The main ones are limited water exchange and a significant river flow, which introduces various pollutants and significantly desalinates the sea water. [Effectiveness of urban wastewater 2005].

The regulation and solution of environmental problems in the Baltic Sea is complicated by the fact that there are nine states on its coast, with significant differences in the environmental legislation. The environmental situation in the Baltic Sea is currently extremely difficult, despite the adoption of a number of international agreements and the Helsinki Convention on the Protection of the Marine Environment of the Baltic Sea Region. [Kartamysheva and Ivanchenko 2017].

A significant contribution to the pollution of the Baltic Sea basin is equally made by all countries 
on its coast, including Russia. The Kaliningrad Amber Plant is one of the most intense sources of negative impact on the ecosystem of the Baltic Sea from the territory of Russian Federation.

The activity of this company is the extraction of natural mineral - amber-succinite. The development of amber deposits at this enterprise is carried out using a combined mining system. It combines the excavation of rock by draglines and the erosion of the enclosing and amber-bearing rocks by hydro monitors with transportation of the resulting pulp through slurry pipelines using a dredger. The tailings, obtained after the extraction of amber from the received pulp, enter the tailing dump located on the beach of the Baltic Sea in the former Pokrovskaya Bay. The total area of the tailing dump is 83 hectares, and the amount of waste accumulated in it at the end of 2016 was more than 573 thousand cubic meters (about 950 thousand tons).

The pulp formed as a result of the erosion of overburden rocks is partially $(\sim 30 \%)$ fed to the tailing dump, partially $(\sim 70 \%)$ to the escarpment fencing of dam of the tailing dump. Such a method of storing overburden is necessary to strengthen the escarpment fencing of the dam, which protects the tailing dump from the destruction by the sea. The artificial water-protective sea beach is injected due to the discharge of pulp and sedimentation of soil particles.

The water entering the tailing dump with pulp, as well as the quarry water, is discharged at a distance of about 20 meters from the water's edge and then it is diverted into the Baltic Sea along the beach. The wastewater undergoes a process of mechanical cleaning (settling) in the settling ponds of the tailing dump before being discharged. Every year, more than 26 million cubic meters of wastewater is discharged into the Baltic Sea at the enterprise.

Nowadays, a direct-flow wastewater system functions at the enterprise and it includes two wastewater discharges. It is the main source of pollution of the Baltic Sea waters on the enterprise. This scheme is irrational, not only from an ecological point of view, but also from a technological one, because it has a number of drawbacks. The main ones include the inefficient use of pumped wastewater, high environmental payments for using the natural beaches of the Baltic Sea to store industrial waste and a high risk of breaking of the tailing dump dam. In addition, the efficiency of wastewater treatment carried out at the enterprise is insufficient, since significant excess concentrations of certain pollutants had been identified [Sokolov et al. 2015].

In this regard, the relevance of the research is justified by the urgent need to conduct wastewater disposal system modernization at the enterprise in question. It will reduce the negative impact on the waters of the Baltic Sea, which have a weak self-recovery potential [Lundstrom 2010].

\section{MATERIALS AND METHODS}

The main methods of research were: system analysis of the fundamental scientific works of Russian and foreign scientists in the field of mining and processing of mineral resources, environmental management, modernization of the wastewater disposal system of industrial facilities through the introduction of a recycled water supply; environmental monitoring and assessment of the quality of wastewater and concentrations of pollutants in the marine water in the impact zone of the enterprise under consideration; mathematical methods for calculating the dilution rate of wastewater when they are discharged into surface water bodies, in accordance with the methods approved in the Russian Federation; the methods of statistical analysis and software calculations for predicting the state of the water basin after the introduction of a recycled water supply and, as a consequence, a decrease in the volume of discharged wastewater.

Environmental monitoring of the state of surface water in the coastal strip of the Baltic Sea, located in the impact zone of the enterprise in question, was conducted in accordance with GOST 17.1.3.07-82 «Nature protection. Hydrosphere. Rules for water quality control of reservoirs and watercourses» [GOST 17.1.3.07-82].

The sampling of wastewater and natural water for analysis under laboratory conditions was carried out in accordance with GOST 31861-2012 «Water. General requirements for sampling» [GOST 31861-2012].

The concentrations of chemical elements in the water samples were investigated with the methods of ion exchange chromatography and atomic absorption spectrometry using highprecision analytical equipment in an accredited Laboratory of Environmental Monitoring of the Saint-Petersburg Mining University, in 
accordance with the approved methods [Scientific instrument base 2018].

The environmental and economic efficiency, and the payback period of the project of the introduction of a recycled water supply at the enterprise under consideration were calculated using the method for calculating the dilution rate of wastewater approved in the Russian Federation [Order of the Ministry of Agriculture 2016] and the method of calculating payments for wastewater discharge [Ministry of Natural Resources 2007].

\section{RESULTS AND DISCUSSION}

The environmental monitoring carried out on the territory of the production enterprise under consideration showed that the discharge of wastewater into the Baltic Sea is carried out through 2 industrial wastewater discharges.

The first discharge of wastewater is classified as concentrated and coastal. The wastewater from the tailing dump and also the quarry water are discharged into the Baltic Sea by the first discharge. Preliminary treatment is carried out only in the settling ponds of the tailing dump and includes gravitational sedimentation of suspended substances. The treatment efficiency is no more than $60 \%$. The treatment of quarry water is not performed at all. The water from tailing dump, as well as the quarry water, is discharged at a distance of about 20 meters from the water's edge and then it is diverted into the Baltic Sea along the beach.

The second discharge of wastewater at the enterprise is the distribution slurry pipeline. About $70 \%$ of all tailings discharge on the slope of dam of the tailing dump through the end discharge of this slurry pipeline. The end discharge of the slurry pipeline is located at a distance of about $50 \mathrm{~m}$ from the Baltic Sea. Such a method of stocking of tailings is necessary to strengthen the barrier dam, which protects the tailing dump from the destruction by the sea. The artificial water protective sea beach is formed due to sedimentation of soil particles in the process of tailings discharge onto a barrier dam. At the same time, the enclosing wastewater flows by gravity into the Baltic Sea.

A quantitative analysis of the wastewater samples from both wastewater discharges was carried out using high-precision analytical equipment at the Laboratory of Environmental Monitoring of Saint-Petersburg Mining University. It showed significant exceeding of standard indicators for some pollutants (Table 1).

The table shows that there is an excess of the maximum permissible values, established for a water body of the highest category of water use [Sinisi and Aertgeerts 2010], for suspended substances, iron, sulfates and chlorides on both wastewater discharges with the existing wastewater disposal system. In this way, the authors came to the conclusion that it is impossible to use the existing wastewater disposal system and there is a need to optimize the environmental activities of the enterprise under consideration.

The authors proposed three different technological solutions for the modernization of the wastewater disposal system on the Amber Plant as a result of analyzing a large amount of scientific literature and project documentation.

The most effective solution from the point of view of environmental protection is the construction of a new tailing dump in the spent space of

Table 1. Results of a quantitative analysis of wastewater samples from both discharges

\begin{tabular}{|l|c|c|c|}
\hline \multicolumn{1}{|c|}{ Pollutant } & $\begin{array}{c}\text { Wastewater discharge No. 1 } \\
\text { Actual concentration, ppm }\end{array}$ & $\begin{array}{c}\text { Wastewater discharge No. 2 } \\
\text { Actual concentration, ppm }\end{array}$ & $\begin{array}{c}\text { Maximum permissible } \\
\text { concentration, ppm }\end{array}$ \\
\hline Suspended substances & 64.300 & 59.250 & 30.000 \\
\hline Biological oxygen consumption & 4.350 & 3.350 & 2.000 \\
\hline Iron & 0.371 & 0.210 & 0.050 \\
\hline Nitrite ion & 0.028 & 0.026 & 0.026 \\
\hline Nitrate ion & 0.675 & 3.318 & 3.318 \\
\hline Ammonium ion & 0.390 & 0.710 & 0.710 \\
\hline Phosphate ion & 0.053 & 0.050 & 0.050 \\
\hline Sulfate ion & 320.175 & 247.750 & 247.750 \\
\hline Chloride ion & 2465.000 & 1141.500 & 1141.500 \\
\hline Dry residue & 6315.000 & 3242.500 & 3242.500 \\
\hline Oil products & 0.012 & 0.011 & 0.011 \\
\hline Copper & 0.005 & 0.002 & 0.002 \\
\hline
\end{tabular}


quarry, with a further transition to a closed recycled water supply [Antonova et al. 2014]. At the same time, the existing tailing dump can be decommissioned and reclaimed. However, the environmental and economic calculations showed that this technological solution requires significant capital expenditures, as well as a large amount of time for creating a new tailing dump. It makes the implementation of such a project economically unfeasible today [Pashkevich et al. 2019].

The second technological solution is the complete technical re-equipment of the enterprise, with the departure from the existing technology of hydraulic erosion, and the transition to a transport scheme for mining, consisting in excavation of rock by draglines. In this case, it is possible to completely eliminate the wastewater discharges as a result of the introduction of closed recycled water supply. Besides, it is possible to create a practically waste-free production, since the overburden rock and the dehydrated amber-bearing rock, after the extraction of amber, can be stored in the spent space of the quarry. The reclamation of the quarry will be conducted by backfilling the spent space [Caruso et al. 2011]. This scheme is promising due to a high degree of preservation of amber and high environmental performance. Unfortunately, it is practically impossible to implement this project today, since it would be necessary to suspend mining operations, which will entail significant losses due to the ever-increasing demand for amber-succinite. In this case, the payback period will be more than 12 years, which is not economically feasible at this stage [Semyachkov et al. 2018].

Therefore, the authors decided that the transition to the recycled water supply is an optimal technological solution for the modernization of the wastewater disposal system of an Amber Plant in terms of its economic and environmental effect, as well as its technological feasibility. This technological solution provides for the use of wastewater accumulating in the tailing dump, as well as all quarry water for the erosion of amber-bearing rock. This decision will lead to a significant reduction in natural water intake and, accordingly, to a reduction in the volume of wastewater discharges into the natural water body (Baltic Sea) due to the complete elimination of wastewater discharge No. 1. [Pashkevich et al. 2013].

The main idea is to build a water-pumping station on the shore of the Baltic Sea in the immediate vicinity of the current wastewater discharge
No. 1 and the laying of the main pipeline. This pipeline will connect the created pumping station with the tailing dump, which will allow using the discharged quarry water and the wastewater from the tailing dump in the recycled water supply, directing them to the hydro monitors to erode the rock [Matveeva et al. 2018].

It is possible to completely eliminate the discharge of wastewater No. 1, using them into recycled water supply for the amber rock water erosion, while implementing the proposed environmental protection solution. At the same time, wastewater discharge No. 2 will remain the same, as the proposed technological solution does not allow to stop the process of strengthening the escarpment of the dam of the existing tailing dump. At the same time, the modernization of wastewater treatment plants will not be required, since the quality of water in the tailing dump and the quality of the quarry water meet the technological requirements for the water used in hydro monitors.

\section{CONCLUSIONS}

On the basis of the study, a diagram was constructed by the authors reflecting the decrease in the volume of wastewater discharged to the Baltic Sea each month as a result of the implementation of the proposed technological solution (Figure 1). While building the diagram, the amount of precipitation falling on this territory in accordance with longterm observations was also taken into account.

The calculations showed that the discharge of wastewater can be reduced by more than $60 \%$ in the case of implementing the proposed scheme of modernization of the wastewater disposal system through the introduction of a recycled water supply. It is possible due to the complete elimination of the discharge of wastewater from the tailing dump and quarry waters (discharge No. 1). At the same time, wastewater discharge No. 22 will remain the same, as the proposed technological solution does not allow to stop the process of strengthening the escarpment of the dam of the existing tailing dump. There is a high risk of erosion of the dam of the tailing dam and - as a result - a man-made disaster in the event that the process of strengthening the dam escarpment on the existing tailing dump is averted.

At the same time, the water withdrawal from the Baltic Sea will be reduced by $70-80 \%$ in the case of the implementation of the proposed water 




$\square$ The wastewater volume discharged into the Baltic Sea before the event, cubic meters

$\square$ The wastewater volume discharged into the Baltic Sea after the event, cubic meters

Figure 1. A diagram reflecting the decrease in the volume of wastewater discharged to the Baltic Sea

disposal system with a partially recycled water supply. Renewal of water intake will be necessary only in the event of a significant drought in the region and a shortage of the volume of circulating water for the realization of the technological cycle of the extraction of amber-succinite. The water supply of the proposed method could be implemented without the need to pump natural water from the Baltic Sea if the amount of precipitation will not be lower than the average perennial.

Moreover, a comparative analysis of the existing materials for water pipes was carried out by the authors. It was decided that the main material from which the water pipes are made corrodes to a large extent, which leads to an increase in the concentration of iron in the wastewater. In this regard, the pipes made of low-pressure high-density plastic have the most optimal technical and economic indicators. They have high strength, are not subject to silting and corrosion and are resistant to abrasive wear. At the same time, they have a significant service life at a relatively low price, due to secondary raw materials are used in their production. The pipes made of low-pressure highdensity plastic do not emit toxic substances into the environment under the conditions of storage and operation; therefore, it is recommended to use this material during the construction of new pipelines and modernization of the existing ones [Sokolov et al. 2015].

The ecological and economic calculations showed that the payback period of the proposed environmental protection measure does not exceed 3 years, while the implementation of this measure will significantly reduce the negative impact on the Baltic Sea ecosystem from the side of this enterprise. Additionally, it will reduce the contribution of the Russian Federation to the integrated pollution of the Baltic Sea by the countries located on coast of the Baltic Sea.

\section{REFERENCES}

1. Antonova I.A., Gryaznov O.N., Guman O.M., Makarov A.B., Kolosnitsina O.V. 2014. Geological conditions for allocation of solid municipal and industrial waste disposal sites in the Middle Urals. Water Resources, 41(7), 896-903.

2. Caruso B.S., Mirtskhulava M., Wireman M. 2011. Mine Water and the Environment, 31(1), 11-13.

3. Effectiveness of urban wastewater treatment policies in selected countries: an EEA pilot study. Copenhagen, European Environment Agency, Report No. 2/2005. URL: http://www.historylab.unina2.it/ files/50.pdf (02.10.2018).

4. GOST 17.1.3.07-82 Protection of nature. Hydrosphere. Rules of water quality control of reservoirs and watercourses.

5. GOST 31861-2012 Water. General requirements for sampling.

6. Kartamysheva E.S., Ivanchenko D.S. 2017. Environmental problems of the Baltic Sea. Young scientist, No. 25. Kazan: Young Scientist Publishing House, 117-120.

7. Lundstrom E. 2010. A different approach to the ecotoxicological characterization of sewage effluent 
using sensitive and ecologically relevant methods. Department of Applied Environmental Science (ITM), Stockholm University, 21-27.

8. Matveeva V.A, Petrova T.A., Chukaeva M.A. 2018. Molybdenum removal from drainage waters of tailing dumps of Apatit JSC. Obogashchenie Rud, Vol. 2, 42-47.

9. Order of the Ministry of Agriculture of the Russian Federation of 13.12.2016, No. 552. On approval of water quality standards for water bodies of fisheries significance, including standards for maximum permissible concentrations of harmful substances in waters of water bodies of fisheries value.

10. Order of the Ministry of Natural Resources of the Russian Federation of 17.12.2007, No. 333. On Approval of the Methodology for the Development of Standards for Permissible Emissions of Substances and Microorganisms into Water Objects for Water Users.

11. Pashkevich M.A., Barkan M.Sh., Nachevkin F.S. 2013. The improvement of the wastewater treatment system at the apatite-nepheline factory. Journal of Mining Institute, 203 (2), 79-82.

12. Pashkevich M.A., Petrova T.A. 2019. Recyclability of ore beneficiation wastes at the Lomonosov Deposit. Journal of Ecological Engineering, 20(2), 27-33.

13. Scientific instrument base of the Saint-Petersburg Mining University. URL: http://old.spmi. $\mathrm{ru} /$ system/files/lib/sci/ckp/ekologicheskoe.pdf (02.10.2018).

14. Semyachkov A.I., Slawikowskaja Y.O., Pochechun V.A. 2018. Methodological features of the assessment of economic damage from adverse environmental consequences in conditions of territories with a developed mining complex. Ecology and Industry of Russia, 22(4), 46-51.

15. Sinisi L., Aertgeerts R. 2010. Guidance on Water Supply and Sanitation in Extreme Weather Events. Regional Office for Europe, DK-2100. Copenhagen, 45-50.

16. Sokolov E.M., Sheinkman L.E., Dergunov D.V. 2015. Provision of environmental safety of mine waters at mining enterprises based on neural network modelling. Journal of Mining Institute, Vol. 211, 96-103.

17. Vesman A.V. 2012. Modern problems of the Baltic Sea. Modern scientific research and innovation, No. 3. URL: http://web.snauka.ru/issues/2012/03/10613 (02.10.2018).

18. Wastewater treatment and access to improved sanitation. European Center for Environment and Health (ENHIS) 2009. URL: http://www.euro. who.int/_data/assets/pdf_file/0009/96957/1.3.Access-to-improved -sanitation-and-wastewatertreatment-EDITED_layouted.pdf (02.10.2018). 